\title{
Characterization of Family Farming in the Semi-Arid Region of Bahia
}

\author{
Deise Cristiane do Nascimento \\ University of the State of Bahia; Master's Degree Student in Human Ecology and \\ Socio-Environmental Management - PPGEcoH; Juazeiro, Bahia, Brazil
}

\section{Maria Herbênia Lima Cruz Santos}

University of the State of Bahia; Professor of the Postgraduate Program in Human Ecology and Socio-Environmental Management - PPGEcoH; Juazeiro, Bahia, Brazil

Received: Nov. 26, 2020

doi:10.5296/jas.v9i1.17997
Accepted: Dec. 27, 2020 Published: Dec. 28, 2020

URL: https://doi.org/10.5296/jas.v9i1.17997

\begin{abstract}
The article aims to characterize the transformations that have occurred in family agriculture by examining the social, economic and political aspects in the semi-arid region of Bahia. It has as its central axis the statement that the rural world remains an important category for the analysis of relations among social classes. For this purpose, a bibliographic review was carried out on the subject, as well as the legal frameworks that legitimize the insertion of family agriculture. This study opted for the adoption of the dialectical materialism method, since the semi-arid region is part of a set that materializes in social, economic and political relations, influencing and receiving influence from the environment. Moreover, based on data from the 2017 Agricultural Census, a quantitative analysis was made by comparing establishments belonging to the family and non-family agriculture categories. Finally, it is believed that this study may contribute to understanding the characteristics of family agriculture and encourage seeking actions and public policies that consider the peculiarities of the farmers' way of life.
\end{abstract}

Keywords: rural, uneven development, public policies, semi-arid

\section{Introduction}

Family farming is understood as that in which the family takes over the work in the productive establishment, while at the same time owning the means of production. Despite being modern, the family farmer maintains peasant traits as he faces the same problems in a contemporary setting, counting in most cases with his workforce (Wanderley, 2003). It is believed that the 
way families relate to production and work differentiate them socially from other production models in the rural world.

The centrality of most natural resources is found in the rural space, and it is there that family agriculture develops, making food production viable due to the availability of land and water resources, which are essential for production. However, the social interaction between means of production and farmers in general occurs according to their local and regional specificities.

As from the 1990s onwards, the rural world began to be widely discussed in Brazil, allowing family farming to understand its reality as an organization model for the agricultural production unit and a heterogeneous group social identity, with cultural and ecological particularities. Economic and political changes in the world scene, as well as the articulation of social movements, represented important spaces for discussion for the advancement of family farming in the national scene (Wanderley, 2001).

The effects of these transformations in the semi-arid territory of Bahia has assumed different proportions. The State's agricultural policy projected in the productive restructuring of the capital has made inversions in the construction of the irrigated perimeter infrastructure. Agricultural public projects have promoted regional dynamism, creating a development hub. On the other hand, the public irrigation policy penalized and excluded the family farmers who were not contemplated, subordinating them to the expanded reproduction system of the capital. In a broader sense, the political option intensified the use of natural resources, promoting an uneven development that worsens during periods of drought (Dourado, 2014).

In spite of that, family farming continues to exist and to resist, building alternatives that make its permanence in such spaces sustainable through the development of strategies that can link the productive activities to subsistence agriculture, commercialization, and possible and diversified non-agricultural activities, Brazilian Semi-Arid Joint [ASA] (2020). Thus, this article aims to characterize the transformations that have occurred in family farming, verifying the social, economic and political aspects in the contemporary society in the semi-arid region of Bahia.

\section{Material and Methods}

The method adopted in the scope of this research was the dialectical historical materialism. For Netto (2011, p. 20), “[...] theoretical knowledge is the knowledge of the research object, of its structure and dynamics, in its real and effective existence". The materialist method favors the social relations established in material production. Through historical information it is possible to identify the transformations in social relations. From the contradictions in social relations, new forms of sociability emerge. The history of society is the history of the antagonistic class fight present in the capitalist mode of production. The central premise involves understanding and explaining the facts in practice.

Netto (2011) mentions that the materialist method uses different research techniques such as bibliographic, documental and content analysis. The bibliographic research was based on the search for papers indexed in databases such as: Scientific Electronic Library Online (Scielo), journals and Google Scholar. Consultations to journals had a chronological cut with time 
delimitation from 2005 to 2020 . Data collection started after the structuring of the documental input, which was essential for its construction, based on normative documents such as Law 11.326 of July $24^{\text {th }}, 2006$, the legal framework on family farming, allowing significant knowledge on the subject.

The study included a review that addressed the themes of family and non-family agriculture, a model of economic and social development, based on some authors (Abramovay, 2007; Wanderley, 2001; Wanderley, 2003; Sabourin, 2009; Pontes, 2012). The data were verified qualitatively through content analysis, which according to Bardin (2016) is a research technique used to make inferences of data valid and reapplicable within their contexts. The organization of the material went through three phases: pre-analysis, exploration of the material and treatment of the results obtained and interpreted.

In the pre-analysis, documents that had the same relationship with the theme and objective of analysis were selected. In general, the material to be investigated was organized, and this systematization enabled the next steps. In the exploration of the material, the texts were analyzed, i.e., codified, and the raw data of the texts were transformed, keeping the relevance and characteristics of the content for analysis. In the third phase - the treatment of the results and interpretation -, the contents contained in the material were analyzed in order to be significant. The interpretation sought the meaning of the messages to reach understanding.

Quantitative data from the 2017 Agricultural Census were also used in this study, with definitive results being published by the Brazilian Institute of Geography and Statistics (IBGE). The Census data presented follow the criteria for delimiting family farming under the terms of the Family Agriculture Law (Law 11.326 of 2006). Thus, it was possible to extract quantitative information on the number of establishments, area, employed people, gross value of production and access to credit.

The results will be presented in three subsections. The first one is the background to the rural economic history, followed by quantitative data on family and non-family agriculture. As for the next subsections, they are dedicated to clarifying the transition from being a peasant to family farmer, as well as economic, social and political features of family agriculture in the Northeast and in the semi-arid region of Bahia.

\section{Results and Discussion}

\subsection{Traits of the Rural Economic History}

The diversity of the various economic zones in which Brazil has been divided did not prevent conflicts due to the exploitation of land and of the labor force. The existence of slave labor, sharecroppers and wage labor marked the commercial character of the economy, which can be seen in the sugar crops concentrated on the coastal strip and in livestock production in the northeastern hinterland. In the post-1964 period, land use without labor legal support was intensified. Labor exploitation is a peculiar trait of capitalist economies, with exceedingly small wages paid to workers in the countryside. The poverty of the population is associated with the land-ownership structure, characterized by the formation of land monopolies (Prado Junior, 2011). 
The occupation of the territory developed diversely in the southern region of the country, the concession of small plots of land to the settlers coming from the European continent being carried out with the intention of guaranteeing the Portuguese occupation. With the suppression of slave trade, the beginning of foreign migration aimed to supply labor in the coffee-growing area crops. According to the availability of natural resources and labor force, the Portuguese invasion process occupied the different territories of the country. In the republican period, the largest extensions of land belonged to big landowners, with the production of cattle and products for export controlling the economic and political life of the new states (Andrade, 2004).

The economic and political formation of Brazil led to social fissures, outlined by a power structure concentrated in the hands of producers of primary export activities who directed their efforts towards external demand. In labor relations, the "forms of land exploration and expansion of production, substantial changes were made in labor relations, intensity and increasingly impoverishment of the poorest groups" (Andrade, 2004, p. 83). The workers no longer controlled the means and instruments of production, selling their workforce in exchange for payment.

Economic history was marked by conflicts among social classes over land ownership as power was linked to the land issue, excluding a large part of the population and impoverishing it. From peasantry to family farming, the actions of different governments at different times contributed to the growth of the exclusion cycle. Government actions were directed towards the most capitalized sectors and the productive sphere of commodities that were destined for the international market, the purpose of this agricultural policy being to achieve the country's trade balance surplus (Pedrão, 2020).

In developed countries, the expansion of family farming has traditionally been associated with access to land, which has particularly taken on a distinct form. In the United States, unlike Brazil, small farms were contemplated by government agencies, the pressure from society having made it possible to maintain policy programs to support rural communities. In their historical process, the distribution and occupation layout of land in small properties in most regions were favored (Navarro \& Pedroso, 2011).

The social reproduction of the capital in those countries contributed to the transition from a rural-based economy to an urban and industrial economy in a socially balanced way. In a different direction, developing countries, mainly in Latin America, showed a social and economic imbalance due to the adopted modernization and industrialization strategy in view of the colonization process in its social and economic aspects (Guanziroli, 2001).

The structural inequality of Brazilian agrarian history can also be seen with the implementation of the Land Law in 1850 in fixing the price of land for squatters and disregarding simple planted plots as characteristics of ownership, limiting the possibility of small property and preserving the land structure. The unequal mode of access to land and its transformations in relation to the sense and meaning of development, of management and cultivation forms reflected in the antagonism of social classes. "The peasant heritage was diverse in the country's regions; in the northeast in the colonial era, interstices between large farms, that of the cowboys 
who bought leagues of land [...] in the south and southeast, European peasants" (Sabourin, 2009, p.281).

These inequalities can be observed in the income earned in family farming, in the access to credit and in the public policies to meet the needs of agricultural production units (Schneider \& Niederle, 2008). To this end, it is understood that the historical aspects of such structure were established as from the moment the Portuguese stopped extracting natural resources, seeking to institute an export agricultural production system based on monoculture and slave labor in the $17^{\text {th }}$ century (Sabourin, 2009).

Between the 1930s and 1960s, the country directed its investments towards forming an industrial base financed by the State. Along with this process, in the late 1950s, the green revolution gave way to a dynamic agriculture with a growth in agricultural production, which occurred through mechanization of the field, use of fertilizers, modified seeds and pesticides. These investments were made due to the availability of credit and public subsidies granted to landowners (Schneider \& Niederle, 2008).

The incentives to modernize large rural properties were reflected in a development marked by disparities. These characteristics of the growth model revealed the migration of labor from rural to urban, leaving family farmers out of the modernization process. In this sense, there is dismay and disregard for family farming for political and economic reasons, which is linked to another class, the rural oligarchy. Power is marked by the high concentration of land, and by other natural and financial resources (Guanziroli, 2001).

"In the second half of the 1960s, when the modernization process was accelerated under the boosting of massive transfer of resources to large landowners by means of the agricultural policy, the actual wages in the countryside were extremely low." As a result, the number of workers who remained unemployed in the agricultural labor market grew, in addition to the low wages to be paid not being enough for modernization to take on a labor mitigating character (Guanziroli, 2001, p. 27).

In this regard, it is important to emphasize that traditional labor relations were unstructured due to the creation of temporary work and the exclusion of permanent work on farms. In view of this, the reform movements in national policy aimed at agrarian reform gained strength, as did the rural workers' and small producers' union organizations (Wanderley, 2014).

As a result, the social rights of rural workers were legalized through the enactment of the Rural Worker Statute ${ }^{1}$. The merit of the Statute was to meet a social demand in the face of the wishes of rural workers. Despite this, the landowners made it difficult to apply the Statute, the high illiteracy rates of workers contributing to the lack of knowledge of their rights, lack of inspection and fear of the boss' violence.

${ }^{1}$ Name given to Law 4.214 promulgated on March $2^{\text {nd }}$, 1963 and published in the Official Gazette on the $18^{\text {th }}$ of the same month. The statute meant the extension of social legislation to rural workers, providing the basis for union organization in the Brazilian countryside. (Vianna, 1963). 
According to Vianna (1963, p. 62) "the boss will out it into practice, with the support and help of the deputy police officer, appointed by indication of the farmers". The reality of the countryside has distanced itself from the legislation to protect rural workers. Another important historical landmark of family farming is found in the Federal Constitution of Brazil, chapter III $^{2}$, Art. 184, which deals with Agricultural and Land Policy and Agrarian Reform (Brasil, 1988).

Waving to social movements the expropriation of unproductive land and the search for territorial reorganization. It also made sure to secure some pillars of proprietary individualism by safeguarding the owner's right, making productive property immune from expropriation by social interest, while not making it clear what was meant by productive property.

Only in 1996 was the National Program for the Strengthening of Family Farming (PRONAF) created, born out of the demand by the movements that occurred in 1994. Movements such as the National Days of Fight which, since 1995, came to be called Cry of the Land Brazil. In this way, PRONAF is one of the first affirmative actions with the objective of financing activities and services addressed to family farmers (Mattei, 2006).

Therefore, information was sought in the database of the Agricultural Census (2017) to categorize the importance of family farming in the economic dynamics: in number of establishments, they totaled $76.8 \%$; with regard to the area, they accounted for $23.2 \%$ of agricultural establishments, being responsible for $1 / 3$ of the gross value of production in agriculture. The average number of employed people was 2.6 per establishment, whereas in non-family farming establishments the average number of employed people was 4.3.

Table 1. Characteristics of agricultural establishments according to the classification of family and non-family agriculture, Brazil (2017).

\begin{tabular}{|c|c|c|c|c|c|}
\hline \multirow[t]{2}{*}{ Characteristics } & & \multicolumn{2}{|c|}{ Family Farming } & \multicolumn{2}{|c|}{ Non-Family Farming } \\
\hline & & Amount & Percentage & Amount & Percentage \\
\hline $\begin{array}{l}\text { Number } \\
\text { establishments }\end{array}$ & of & $3,897,408$ & $76.8 \%$ & $1,175,916$ & $23.2 \%$ \\
\hline Area (ha) & & $80,891,084$ & $23 \%$ & 2.703 .98 .732 & $77 \%$ \\
\hline Employed People & & $10,115,559$ & $67 \%$ & $4,989,566$ & $33 \%$ \\
\hline $\begin{array}{l}\text { Gross Value } \\
\text { Production }\end{array}$ & of & $\begin{array}{c}106,489,05 \\
2\end{array}$ & $23 \%$ & $358,616,863$ & $77 \%$ \\
\hline
\end{tabular}

Source: IBGE - Agricultural Census (2017)

2 Agricultural and Land Policy and Agrarian Reform, art. 184. 
The data in Table 1 show that non-family agriculture, also known as patronal, detained $77 \%$ of area. Despite this, in number of establishments, they were only $23.2 \%$ and made up $77 \%$ of the gross value of production. On the other hand, family farming in number of establishments corresponded to $76.8 \%$ of the activity in approximately $23 \%$ of the area, contributing $23 \%$ of the gross value of production.

The absolute number of people employed in family farming was significantly higher, but the average labor productivity $\left(\mathrm{PmeL}^{3}\right)$ lower by around 10.5 when compared to non-family farming, an activity that takes up less labor. The PmeL for patronal agriculture was around 71.9, that is, 6.8 times higher. These data indicate that family farming is intensive in live labor, adding value to the means of production.

"Labor productivity is determined by the most diverse circumstances, among them [...] the efficiency of the means of production and the natural conditions". Labor is the interaction between man and nature, thus, a condition to man's existence (Marx, 2014, p. 62). Mechanization of the countryside is believed to have been able to promote scale gains; however, it did not improve the worker's condition regarding employment generation.

Still according to the agricultural censuses of 2006 and 2017, the Gini index ${ }^{4}$ of rural establishments in Brazil went from 0.858 to 0.867 , and over eleven years there has always been a high concentration of land. In accordance with the facts described above, it can be estimated that it was the investments, such as government subsidies at different times in history, which aimed at boosting production, as well as the expansion of accessible lines of credit targeted at the implementation of the technology package.

In the second decade of the $21^{\text {st }}$ century, the effects of this situation can be observed, since agriculture had an average of 3.2 employed people per establishment in 2006, with a reduction to 3.0 people in 2017 . On the other hand, the number of tractors grew by $49.9 \%$ in the period, reaching 1.22 million units, confirming a class of farmers with access to financial resources who invested in the adoption of machinery, heating up the industrial production as well (IBGE, 2018).

"The modern industry operates more revolutionarily in agriculture than in any other sector, by destroying the bulwark of the old society, the peasant, replacing him with the wage-earning worker" (Marx, 2014, p. 570). Modernization brought along a new configuration of the spatial organization of agriculture, changing, in addition to the ways of producing, the relations

3 Average labor productivity is the total product divided by the total quantity of labor input (Pindyck \& Rubinfeld, 2013). As a proxy variable, the gross value of agricultural production was used, representing an estimate of rural income generation.

4 The Gini index is a coefficient for measuring inequality that varies between 0 and 1 , used mainly in studies on income distribution. In the case of the study on land distribution, 0 corresponds to complete equality (land is equally divided among estates), so the closer the value is to 1 , the more unequal the distribution of land will be. [...] it measures relative inequality among landholders rather than concentration (Leite, 2018, p. 13). 
between man and nature. In these circumstances, the social characteristics of productive inclusion and resistance of family farmers must be known.

\subsection{Transition From Peasant to Family Farmer}

The debate around the social categories of family and peasant agriculture is guided by two perspectives: the first one considers family farming modern and unquestionably a new category generated from the social, political and economic transformations of the capitalist societies, besides presenting as a central characteristic the fact that the State control over its development process is "[...] highly integrated into the market, capable of incorporating the main technical advances and of responding to government policies, and cannot be characterized as peasant" (Abramovay, 2007, p. 33).

In the analysis of the differentiation among the social categories, peasants are family farmers who have a partial interaction in markets, that is, partly self-employed and partly integrated into diversified markets. The peasant cannot be characterized as an occasional or transitory class. Indeed, their cultural traits and way of being are relative to the environment in which they live. The term family farmer is another category, although it has a common family background (Abramovay, 2007).

In addition to the above, there is the fact that the peasant does not maximize profit or income. "In this way, the logic of marginal analysis is inapplicable, since, for the peasant, the notion of reducing marginal utility of work is faced with the notion of satisfying his needs" (Pontes, 2012, p 36). In the marginalist school, consumption boosts economic activity as the utility of goods meets needs, opposing the classical school, since the dynamics of the supply of goods and services would lead to the improvement in the living conditions of the individuals. In turn, the peasant's work in the production of consumer goods aims to meet the family's needs and subsistence, unlike the profit for the companies.

Pontes (2012), when analyzing the thought of Chayanov (1966), interprets the Russian agrarian history highlighting the class rupture, the peasants would increase their production with the fall in prices. This answer would contradict the capitalist production model, since the tendency of companies is to reduce production when prices fall. Being a peasant is a way of life and work, not a profession as it happens in family farming.

In another perspective, Wanderley (2003) considers family farming a category in transformation, breaking but at the same time keeping characteristics of its traditional peasant past. There is no difference between the social categories, but rather a continuity, that is, the transition from traditional peasant to family farmer, maintaining their historical peasant roots.

Wandeley (2014) defines the peasantry as a social form of production, focused on family needs; regarding the way work is organized, there is a tendency for cooperation among its members, emphasizing their past and their traditions. In Brazil, during the military governments from 1965 to 1985 , the meaning of being a peasant had a strong political content. Being persecuted and considered subversive, they were then called small farmers, subsistence farmers and low-income farmers, which, in addition to imprecise connotations, carried a strong depreciating content. 
The family farmer is a contemporary social actor integrated to the rural environment, responding to market demands. They preserve traits of the peasant tradition, under different conditions and forms. They are dedicated to family subsistence and use cultural diversification strategies, introducing the notion of progress. However, the changes have not prevented the continuation of certain practices or of their family representations. In this way, peasantry and family farming can be understood as equivalent (Wanderley, 2003).

Sabourin (2009, p. 342) complements Wanderley's idea (2003), stating that especially in the Northeast the "[...] wide category of family farming, the case studies addressed confirm the existence of an agriculture with peasant characteristics, marked mainly by autonomy towards the capitalist exchange market", with a diversified production and inserted in the local markets, as well as directed towards self-consumption, maintaining the practice of inter-family redistribution. Thereafter, it is believed that it is appropriate to consider that modernization in the countryside has not eliminated the peasant way of life, but inspired and guided family farming.

The transition from peasant agriculture to agriculture integrated to the market is what characterizes the contemporary family farmer, where a capital-work relationship is established, maintaining the existence of a possible continuity between both forms of agriculture (Wanderley, 2003). In addition to the contradictions, we can see that there are agricultural farmers in the Brazilian rural environment who are related due to the reference to family patrimony, thus building a way of life and a way of working, the centrality consisting of family and neighboring ties (Wanderley, 2014).

In view of the changes in the capitalist mode of production and of the importance of family farming as a social and economic category, the legislation defined who can be considered a family farmer. Since there is no universal concept of what is meant by family farming, Law 11.326 (Brasil, 2006) establishes guidelines for the formulation of the National Policy for Family Farming and Rural Family Enterprises, as well as conceptualizing the family farmer and rural family entrepreneur in art. 3:

[...] those who practice activities in rural areas, simultaneously meeting the following requirements: I - do not hold, in any capacity, an area larger than 4 (four) fiscal modules; II - use predominantly their own family's labor in the economic activities of their establishment or enterprise; III - have a minimum percentage of family income from economic activities of their establishment or enterprise; IV - run their establishment or enterprise with their family.

$\S 2$ The following are also beneficiaries of this Law: I - foresters; II fish farmers; III - extractivists [..] carry out this activity artisanally in rural areas, excluding miners and sparklers; IV - fishermen [...] and carry out the artisanal fishing activity; V - indigenous peoples; VI members of the remaining communities of rural quilombos and other traditional peoples and communities [...]. 
Law 11.326 (Brasil, 2006) legally delimited the concept of family farming, produced interpretations and proposals for public policies for the Brazilian rural sector, observed both socioeconomic and cultural aspects of identification, was consistent with their way of doing farming, taking into account their contribution to food sovereignty, with the perspective of being socially fair, economically viable and environmentally sustainable.

\subsection{Northeast and the Uneven Rural Development}

During the 20th century, regional policies that transformed the productive structures of the northeastern states were proposed, with emphasis on the industrialization policy that was concentrated in Bahia, Pernambuco and Ceará. In addition, the developmental projects corroborated to trigger conflicts, social and environmental injustices. Economic backwardness and problems strengthened the Peasant Leagues that put pressure on the Federal Government to implement effective actions to mitigate land concentration and income disparities (Diniz \& Piraux, 2011).

Considering that, it is necessary to bring to light the mismatches of the classic model of development from the early 1960s. The essential problem about the proposed national paradigm was that it favored the center-southern region of the country, essentially the bourgeoisie from urban areas, with the distortions of a policy that concentrated income and incorporated productivity gains in the industry. Meanwhile, the northeastern region remained as primary exporter, importing industrialized products. Thus, interregional trade imposed the importation of industrialized consumer goods while facilitating the importation of capital goods and inputs to supply the needs of the industrial pole, accentuating inequalities and causing the deterioration of the means of exchange, which was represented in the transfer of income to the Center-south (Furtado, 1981).

Thus, the strategy outlined by the State was the elaboration of a master plan for the hydro-agricultural use, partly due to droughts, but also in favor of the concentration of power and its potential for territorial expansion. Among the actions, there was the construction of reservoirs, small dams, tubular wells, dams on large properties and irrigation districts. Structural investments with an assistentialist and paternalistic nature in the irrigation perimeters of the semi-arid region of Bahia allowed the creation of a modern pattern for business agriculture, not taking into account the way of life and the production of the traditional population, thus taking the form of exclusion (Dourado, 2014).

The power of public policies is related to their disposal to interfere in the concrete situations in which people live. It can be said that emergency policies to combat drought and its effects have promoted economic growth and contributed to a system of capital accumulation by local dominant elites, strengthening the political, economic and ideological power, which characterized the Oligarchic State. The concentrated agrarian structure favored solutions that did not imply changes, but social control and deterioration of labor (Diniz \& Piraux, 2011).

In addition, rural credit, one of the central elements of the agricultural modernization process, is concentrated in the South and Southeast of the country, once capitalized producers offer greater possibility of financial return to banks, strengthening the sectoral and productivist logic 
of patronal agriculture. As of 2007, the northeastern region, which had half of the potential beneficiaries, achieved around $15 \%$ of the total invested funds. This imbalance demonstrated its incompatibility with the rationality of a national public policy (Aquino \& Schneider, 2015).

Furthermore, it is necessary to highlight the characteristics and contribution of northeastern family farmers identified by the Census (IBGE, 2017). The existence of 1,838,846 establishments was verified, that is, $79 \%$ of the total in relation to the $25,925,743$ hectares in occupied area. The contribution of family farming to agricultural production was expressive, as $30 \%$ of the gross value of production and $74 \%$ of the total agricultural jobs come from those farmers, which resulted in PmeL 3,4. On the other hand, the concentration of land in non-family farming is noticeable, $63 \%$ of the area (ha) along with a lower number of jobs and a higher than PmeL 16, 6 when compared to family farming, which occurs due to the countryside mechanization (Table 2). It is also important to mention that, according to data from the Agricultural Census (2017), the Northeast concentrated $47 \%$ of the family farming establishments in the country.

Table 2. Characteristics of agricultural establishments in the Northeast, according to the classification of family and non-family agriculture (2017)

\begin{tabular}{l|c|c|c|c}
\hline \multirow{2}{*}{ Characteristics } & \multicolumn{2}{|c|}{ Family Farming } & \multicolumn{2}{c}{ Non-Family Farming } \\
\cline { 2 - 5 } & Amount & Percentage & Amount & Amount \\
\hline Number of establishments & $1,838,846$ & $79 \%$ & 483,873 & $21 \%$ \\
Area (ha) & $25,925,743$ & $37 \%$ & $44,968,122$ & $63 \%$ \\
Employed People & 4708670 & $74 \%$ & 1668094 & $26 \%$ \\
Gross Value of Production & $15,878,992$ & $30 \%$ & $37,673,989$ & $70 \%$ \\
\hline
\end{tabular}

Source: IBGE - Agricultural Census (2017)

In Figure 1, it is possible to verify that in relation to the number of establishments, only $34.44 \%$, managed to access resources from government programs of credit, such as PRONAF, Implementation and Installation of Settlements (Institute of Colonization and Agrarian Reform - INCRA), Strong Land and Sun Land Program, among others. 47.1\% are farmers excluded from the rural credit program due to socioeconomic conditions who in general end up paying more for the loans they make.

The other distributions are equivalent to $26.18 \%$ in the Center-West, $29.25 \%$ in the North, $42.26 \%$ in the Southeast and 53, 95\% in the South. Family farmers from the South have the highest percentage of establishments with access to lines of credit. Access to credit is uneven, as it is not concentrated in regions with a higher number of establishments such as the Northeast, but it is related to other factors, such as the value of production and the guarantees 
offered. Indeed, the growth in both family and non-family agricultural production is inseparable from public policies and State actions. These actions demonstrated their fragility, since inequalities persist among the regions.

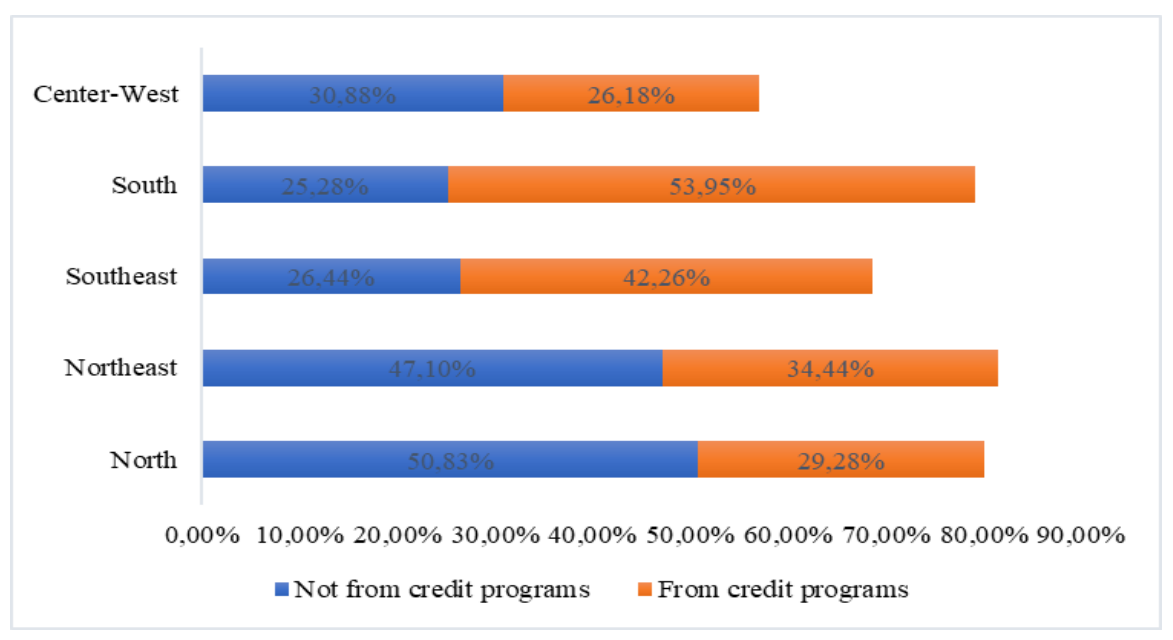

Figure 1. Percentage of financed agricultural establishments, family farming

Source: IBGE - Agricultural Census (2017)

The resilience of family farming in relation to the social and economic issues that are faced has changed its dynamics in face of the imposed developmental model, which benefited modern agriculture without looking at cultural and environmental issues. Family farmers have demonstrated that they generate more jobs, have a greater number of productive units, and contribute significantly to the composition of the total volume produced.

\subsection{Delimitation and Characterization of Family Farming in the Semi-Arid Region of Bahia}

The Brazilian semi-arid has approximately $982,563.3 \mathrm{~km}^{2}$, around $10.5 \%$, that is, $103,589.96$ $\mathrm{km}^{2}$, is in the state of Minas Gerais. The largest land concentration, 89.5\%, belongs to the northeastern region, distributed among its states apart from Maranhão. The first delimitation occurred by Law 7.827 (Brasil, 1989), the most recent delimitation of the area being carried out by Resolution 115 of November $23^{\text {rd }}, 2017$ of the Northeast Development Superintendence (SUDENE).

With approximately 27 million inhabitants, about $12 \%$ of the Brazilian population, the delimitation is distributed in 1,262 municipalities, 278 being in Bahia. According to the delimitation of the Brazilian semi-arid region, municipalities with an average annual rainfall equal to or smaller than $800 \mathrm{~mm}$ are included, with an aridity index of up to 0.5 and a drought risk greater than 60\% regarding the period from 1970 to 1990 (SUDENE, 2018). In relation to periods of drought, public policies were developed based on that problem.

In 1904, the government created a budget allocation followed by three commissions: "one for dams and irrigation, one for studies of works against the effects of drought, and one for drilling wells against the effects of drought and for drilling of wells", according to Suassuna (2007, p. 136). The first commission to start the work was that of works against drought in 
October 1909. Only one remained, that of dams and irrigation, the others did not present satisfactory actions, accentuating the problems related to social and environmental issues.

In Sen's ideas (2018), the imperfections of the State's actions in the organization of society widened the inequality gap. Justice and equality are fundamental to promote the expansion of political freedoms, of social opportunities, of guarantees of transparency and protective security. Among the forms of deprivation of freedom there are hunger, the malnutrition that can affect many human beings, the lack of access to health services, basic sanitation and treated water.

Inequality between men and women ends up shortening the lives of millions of women by restricting their degree of freedom. Actions aiming at combating forms of exclusion have the power to influence their surroundings and future generations. Other forms of suppression, such as masked slavery, denial of labor rights and child labor are impediments to the emergence of freedom of employment (Sen, 2018).

In more precise terms, macroeconomics in determining the full use of production factors, the social welfare State and the need to correct the microeconomic markets' myopia and the indifference determine important characteristics of a system of capital reproduction, abstracting the social issue (Pedrão, 2020).

Ki-Zerbo (2010) reveals that when trying to dominate the economic culture, specialists in economic development ignore environmental conditions, the relationship between man and the land, while destructuring the population's confidence in itself, endogenous development being the passage from one to oneself at a higher level, in an exchange relationship with others, and not in a race to recover what is impossible.

In view of this, Daly (2004, p. 198), discusses economic growth as a paradox because it is uneconomical in promoting an increase in the environmental and social cost as it depletes natural resources, not allowing the regeneration of the ecosystem. The proposal for a steady state $^{5}$ would be ideal, given that the "terrestrial ecosystem develops (evolves), but does not grow. Its subsystem, the economy, must finally stop growing, but it can continue to develop".

According to the proposed actions underway, Pedrão (2020, p. 157) highlighted the urgency of a regional policy capable of understanding the edaphoclimatic conditions with adapting the productive system to the physical environment. The water crisis, the accumulated effects of deforestation practices followed by equivocal policies contributed to the fact that Bahia would "see its territory recognized as semi-arid going from $65 \%$ to $78 \%$ in this century. What is on the agenda is not a technical development of the semi-arid region, but the social enhancement of the hinterland society that lives in the semi-arid region", as well as the concentrated land-ownership structure having contributed little to resolving social issues.

\footnotetext{
5 "This theorem sustains that maintaining current patterns of consumption of natural resources is not viable on an overpopulated planet. In other words, the growth in per capita consumption is incompatible with the population growth. This would inevitably lead to a serious environmental crisis" (Daly, 2004, p. 201).
} 
In view of this, Conti and Pontel (2013) point to possible alternatives that emerged in the first half of the $20^{\text {th }}$ century with the articulation of rural workers and their organizations that demanded permanent agrarian and agricultural policies about coexisting with the semi-arid with principles of sustainability, technological efficiency, productive rationality. Programs and actions carried out by the government so that the worker and small rural producer would benefit have somehow corrected the structural and secular distortions that have perpetuated rural poverty and misery.

Diniz and Piraux (2011, p. 233) emphasize that living with the semi-arid region is characterized by a "cultural perspective guiding emancipatory processes, the expansion of creative and creating capacities of the region's population". In other words, a strategic guideline that will change reality, coexisting with environmental specificities. In 2003, the Zero Hunger Program aimed to combat poverty and hunger in Brazil, when the priority area was the semi-arid. As a result, government interventions favored family farming, respect and dignity between men and women in the countryside.

The objective of the actions are forms of coexistence with the semi-arid and that valuing the caatinga biome and its potentialities. Among them, the production and storage of goods in rainy periods to be used in times of water scarcity, social technologies that enable access to water, seed storage. Built with the participation of society, in harmony with its culture and its traditional knowledge, enhancing the conditions for production and prioritizing the sustainable use of natural resources (ASA, 2020).

In the semi-arid region of Bahia, like other territories in Brazil, there is high land inequality, as a large proportion of the total area is occupied by a small proportion of establishments (Hoffmann \& Ney, 2010). This reality is noticeable when comparing the area occupied by non-family and family farming producers, as from the data in Table 3. At first, the contrast between the number of establishments classified as family farming and the area occupied by these establishments and the equivalence of these numbers for non-family farming must be highlighted.

While $78 \%$ of agricultural establishments were delimited as the profile of family farming and held an area of $38 \%$, the other $22 \%$ were classified as non-family and gathered an area corresponding to $62 \%$, which demonstrates considerable land concentration. The latter have an average area of 98.12 ha, which corresponds to six times the size of the family productive area. 
Table 3. Characteristics of agricultural establishments in the semi-arid region of Bahia, according to the classification of family and non-family agriculture (2017)

\begin{tabular}{l|c|c|c|c}
\hline \multirow{2}{*}{ Characteristics } & \multicolumn{2}{|c|}{ Family Farming } & \multicolumn{2}{c}{ Non-Family Farming } \\
\cline { 2 - 5 } & Amount & Percentage & Amount & Amount \\
\hline Number of establishments & 462684 & $78 \%$ & 128712 & $22 \%$ \\
Area (ha) & $7,678,78$ & $38 \%$ & $12,630,503$ & $62 \%$ \\
& 5 & & & \\
Employed People & 1185363 & $74 \%$ & 410578 & $26 \%$ \\
Gross Value of Production & 3679770 & $33 \%$ & $7,567,585$ & $67 \%$ \\
\hline
\end{tabular}

Source: IBGE - Census of Agriculture (2017)

Family farmers employed $74 \%$ of the workforce of agricultural establishments, with gross value of production of $33 \%$ of the total activity and PmeL 3.10, despite the difficulties regarding access to credit, only $25 \%$ having obtained funding through PRONAF, further $9.8 \%$ coming from other credit programs. Inequalities remain when analyzing the differences between men and women in the position of family farmers and producers in relation to land (74\% and $26 \%$ respectively) in the number of establishments. In smaller numbers, women play an important role in the field of production as they are precursors within the family unit in taking on challenges to start something new.

\section{Conclusion}

Family farming throughout Brazil's socioeconomic history has demonstrated its capacity for transformation in view of the capitalist mode of production. In fact, this form of social and economic organization, managed by the family with predominance of family labor, work and management seen in an interconnected way, has survived and been present in people's daily lives due to the food they produce. Seen as a system composed of a set of elements in interaction with each other and with the external environment, it contributes to the social and economic aspects, generating jobs and income.

In general, family farming absorbs a greater number of employed people, which enables growth in the generation of jobs and income. The relationship with the land is valued for being their place to live, in the sense of prioritizing environmental sustainability. The family farmer does not aim to overburden the environment by depleting the land, so because of that and of the access to other variables, PmeL is lower when compared to patronal agriculture, due to the access and use of higher capital technologies. On the other hand, patronal agriculture consolidated with the irrigation process and changes in social relations has made this activity profitable for the owners of capital, strengthening the power of the dominant oligarchy. For the 
families of the semi-arid region in Bahia, the commercialization of their labor force was what was left as an alternative, as a source of income.

Indeed, the actions of the State have accentuated social antagonism, the investments made having created distortions as regards access to land and water, a reality that has become an obstacle to the development of the rural environment. The modernization process of agriculture is uneven, contradictory and has brought land concentration. The contribution of family farming is unquestionable for society, the articulation with the coexistence of the semi-arid having put under discussion the agenda for a fairer model, respectful in principle, to reduce disparities, and taking into account the culture and the appreciation of the farmers' experience and knowledge in the articulation of those workers who have sought permanent actions from the State to foster development.

\section{References}

Abramovay, R. (2007). Paradigmas do Capitalismo Agrário em Questão. $3^{\mathrm{a}}$ ed. - São Paulo: Edusp.

Andrade, M. C. de O. (2004). A questão do território no Brasil. $2^{\mathrm{a}}$ ed. São Paulo: Hucitec.

Aquino, J. R. D., \& Schneider, S. (2015). Pronaf e o desenvolvimento rural brasileiro: avanços, contradições e desafios para o futuro. Políticas públicas de desenvolvimento rural no Brasil. Porto Alegre: Editora da UFRGS, 624.

Articulação Semiárido Brasileiro [ASA]. (2020), Sobre Nós - História. Disponível em: http://www.asabrasil.org.br/sobre-nos/historia. Acesso em: nov. 2020.

Bardin, L. (2016). Análise de conteúdo. São Paulo: Edições 70.

BRASIL. [Constituição (1988)]. Constituição da República Federativa do Brasil. Disponível em:https://www2.senado.leg.br/bdsf/bitstream/handle/id/518231/CF88_Livro_EC91_2016.pd f. Acesso em: 04 de set. 2020.

BRASIL. [Lei n. 11.326 (2006)]. Estabelece as diretrizes para a formulação da Política Nacional da Agricultura Familiar e Empreendimentos Familiares Rurais. Diário Oficial da União, Brasília, 2006.

Conti, I. L., \& Pontell, E. (2013). Transição paradigmática na convivência com o Semiárido. In: Conti, I. L., \& Schroeder, E. O. (2013). Convivência com o semiárido brasileiro: autonomia e protagonismo social. Editora IABS. Brasília-DF.

Daly, H. E. (2004). Crescimento sustentável? Não, obrigado. Ambiente \& sociedade, 7(2), 197-202. https://doi.org/10.1590/S1414-753X2004000200012

Diniz, P. C. O., \& Piraux, M. (2011). Das intervenções de combate à seca às ações de convivência com o semiárido: trajetória de 'experimentalismo institucional'no semiárido brasileiro. Cadernos de Estudos Sociais, 26(2).

Dourado, J. A. L. (2014). Projetos desenvolvimentistas nas terras do sem-fim: Expansão do agronegócio e precarização do trabalho no semiárido baiano. Sociedade \& Natureza, 26(1), 
7-23. https://doi.org/10.1590/1982-451320140101

Furtado, C. (1981). Uma política de desenvolvimento para o Nordeste. Rio de Janeiro: Imprensa Nacional.

Guanziroli, C. E. (2001). Agricultura familiar e reforma agrária no século XXI. Editora Garamond.

Hoffmann, R., \& Ney, M. G. (2010). Evolução recente da estrutura fundiária e propriedade rural no Brasil. Gasques et al 2010a, 45-64.

Instituto Brasileiro de Geografia, \& Estatística. (2017). Censo agropecuário 2017, IBGE.

Instituto Brasileiro de Geografia, \& Estatística. (2018). Censo Agro 2017: população ocupada nos estabelecimentos agropecuários cai 8,8\%. Disponível em: https://www.ibge.gov.br/. Acesso em 20 de jul. 2020.

Ki-Zerbo, J. (2010). História Geral da África, Vol. I- Metodologia e pré-história da África. Brasilia:Unesco

Leite, A. Z. (2018). Análise da concentração fundiária no Brasil: desafios e limites do uso do índice de Gini/Land concentration analysis in Brazil: challenges and limits of the Gini index. REVISTA NERA, (43), 10-28.

Marx, K. (2014). O Capital: Crítica da Economia Política. Livro I, Rio de Janeiro, 32ª ed. Civilização Brasileira.

Mattei, L. F. (2006). Produção acadêmica sobre o Programa Nacional de Fortalecimento da Agricultura Familiar. UFSC, Florianópolis, SC. Disponível em: https://www.researchgate.net/publication/266471581_PRODUCAO_ACADEMICA_SOBRE O_PROGRAMA_NACIONAL_DE_FORTALECIMENTO_DA_AGRICULTURA FAMILIAR. Acesso em: 30 de set. 2020.

Navarro, Z., \& Pedroso, M. T. M. (2011). Agricultura familiar: é preciso mudar para avançar. Embrapa Estudos e Capacitação-Texto para Discussão (ALICE).

Netto, J. P. (2011). Introdução ao método da teoria. São Paulo: expressão popular.

Pedrão, F. C. A dinâmica do subdesenvolvimento e a tensão hídrica na Bahia. Informe GEPEC, 24(1), 151-161. Disponível em: http://e-revista.unioeste.br/index.php/gepec/article/view/23762. Acesso em: 06 de out. 2020.

Pindyck, R. S., Rubinfeld, D. L., \& Rabasco, E. (2013). Microeconomia. Ed. Pearson.

Pontes, B. M. S. (2012). A organização da unidade econômica camponesa: alguns aspectos do pensamento de Chayanov e de Marx. Revista Nera, (7), 35-47. Disponível em: https://revista.fct.unesp.br/index.php/nera/article/view/1455. Acesso em: 30 de abril de 2020.

Prado Jr, C. (2011). Formação do Brasil contemporâneo. Editora Companhia das Letras.

Sabourin, E. (2009). Camponeses do Brasil: entre a troca mercantil e a reciprocidade. 
Garamond.

Schneider, S. (2003). A pluriatividade na agricultura familiar. Editora da UFRGS.

Schneider, S., \& Niederle, P. A. (2008). Agricultura familiar e teoria social: a diversidade das formas familiares de produção na agricultura. Savanas: desafios e estratégias para o equilíbrio entre sociedade, agronegócio e recursos naturais. Planaltina, DF: Embrapa Cerrados, 989-1014.

Sen, A. (2018). Desenvolvimento como liberdade. Editora Companhia das letras.

Suassuna, J. (2007). Semi-árido: proposta de convivência com a seca. Cadernos de estudos sociais, 23(1-2).

SUDENE, S. D. D. D. N. (2018). Delimitação do Semiárido. Disponível em: https://www.gov.br/sudene/pt-br/assuntos/projetos-e-iniciativas/delimitacao-do-semiarido.

Acesso em: 01 de set. 2020.

Vianna, R. S. (1965). O estatuto do trabalhador rural e sua aplicação: comentários à Lei $n$. 4. 214, de 2 de marco de 1963. Livraria Freitas Bastos.

Wanderley, M. D. N. B. (2001). A ruralidade no Brasil moderno: por um pacto social pelo desenvolvimento rural. Una nueva ruralidad en América Latina, 31-44. Disponível em: http://bibliotecavirtual.clacso.org.ar/ar/libros/rural/wanderley.pdf. Acesso em: 01 de set. 2020.

Wanderley, M. D. N. B. (2003). Agricultura familiar e campesinato: rupturas e continuidade. Estudos sociedade e agricultura. Disponível em: https://wp.ufpel.edu.br/leaa/files/2014/06/Texto-6.pdf. Acesso em: 12 de jul. 2020.

Wanderley, M. D. N. B. (2014). O campesinato brasileiro: uma história de resistência. Revista de economia e sociologia rural, 52, 25-44. Disponível em: https://doi.org/10.1590/S0103-20032014000600002

\section{Copyright Disclaimer}

Copyright for this article is retained by the author(s), with first publication rights granted to the journal.

This is an open-access article distributed under the terms and conditions of the Creative Commons Attribution license (http://creativecommons.org/licenses/by/4.0/). 